\title{
Integrative Weaning Index: A Few Observations
}

Sir,

I read with interest the article by El-Baradey et al.$^{[1]}$ and would like to make the following observations:

1. The authors had taken a mixed group of patients in contrast to the study by Nemer et al. ${ }^{[2]}$ where patients with respiratory diseases formed the major bulk. However, the reason for intubation and mechanical ventilation is not clear in the groups "brain tumor" and "morbid obese" and hence, needs further clarification. In the groups of "head trauma" and "major abdominal surgery" was the intubation and mechanical ventilation done perioperatively or was it done to protect the airway? - This aspect needs to be elucidated by the authors. Even the group "respiratory failure" (which constitutes the majority of the patient load in most of the Intensive Care Units) seems vague (type 1 vs. type 2 vs. mixed?) and essentially constituted a minority of the patients. The disease profiles of the groups lead us to wonder, since a vast proportion of the patients did not have a significant pulmonary dysfunction altering the pulmonary mechanics (why would a brain tumor patient with no "respiratory failure" have a pulmonary derangement), whether the use of the integrative weaning index (IWI) was justified in the given set of patients as IWI uses compliance of the respiratory system (Cst) and $\mathrm{SpO}_{2}$ as components which should be by and large normal in these categories of patients

2. In the criteria of readiness of weaning, the authors have mentioned a number of parameters which was uniformly used in both the groups (Group I and C) like respiratory rate (RR)/tidal volume (TV) $<105 / \mathrm{bpm}$ etc. This implies that the rapid shallow breathing index (RSBI) has been used in both the groups before randomization to the "routine criteria of weaning" and IWI. Now, the RSBI $<105 / \mathrm{min}$ itself has a sensitivity and positive predictive value of $97 \%$ and $78 \%$, respectively. ${ }^{[3]}$ Hence, the poor performance of the Group C (26 weaning failure out of 60 cases) seems very difficult to explain and the authors should throw light on to the perceived reason for the same

3. While the authors have done a commendable job in bringing forth the utility of IWI some errors have not been weeded out, most notably:

- The formula for IWI has been mentioned twice in the article and both times it has been formulated as IWI $=$ Cst $\times \mathrm{SaO}_{2} \times \mathrm{RR} / \mathrm{TV}$ while the correct formula as suggested by Nemer et al..$^{[3]}$ is $\mathrm{IWI}=\mathrm{Cst} \times \mathrm{SaO}_{2} / \mathrm{RR} / \mathrm{TV}$

- In the Group I as mentioned in Table 1 (vide the article by the same authors) the total number of patients accounted for is $14+6+6+17+11+8$ is 62 while the group originally had 60 patients.

\section{Financial support and sponsorship}

Nil.

\section{Conflicts of interest}

There are no conflicts of interest.

Animesh Ray
Department of Pulmonology Critical Care and Sleep Medicine,
Fortis Hospital, New Delhi, India
Address for correspondence: Dr. Animesh Ray,
Department of Pulmonology Critical Care and Sleep Medicine,
E-mail: doctoranimeshray@gmail.com




\section{ReFERENCES}

1. El-Baradey GF, El-Shmaa NS, Ganna SA. Can integrative weaning index be a routine predictor for weaning success? Indian J Crit Care Med 2015;19:703-7.

2. Nemer SN, Barbas CS, Caldeira JB, Cárias TC, Santos RG, Almeida LC, et al. A new integrative weaning index of discontinuation from mechanical ventilation. Crit Care 2009;13:R152.

3. Yang KL, Tobin MJ. A prospective study of indexes predicting the outcome of trials of weaning from mechanical ventilation. N Engl J Med 1991;324:1445-50.
This is an open access article distributed under the terms of the Creative Commons Attribution-NonCommercial-ShareAlike 3.0 License, which allows others to remix, tweak, and build upon the work non-commercially, as long as the author is credited and the new creations are licensed under the identical terms.

\begin{tabular}{|l|l|}
\hline \multicolumn{2}{|c|}{ Access this article online } \\
\hline Quick Response Code: & Website: \\
\hline & www.ijccm.org \\
\cline { 2 - 2 } & \\
& \\
\end{tabular}

How to cite this article: Ray A. Integrative weaning index: A few observations. Indian J Crit Care Med 2017;21:805-6.

C 2017 Indian Journal of Critical Care Medicine | Published by Wolters Kluwer - Medknow 